\title{
A NEW FUNGUS FOR PUERTO RICO
}

Rhyytisma leptospilum Berk. \& Curt. is the tentative determination by Dr. W. W. Diehl of the immature stage of a fungus found on the tender leaf of "almendrón", Prumus occidentalis, at Villalba on August 2, 1954, as reported by John A. Stevenson, in charge, Section of Plant Disease Epidemics and Identification Section, Horticultural Crops Research Branch, ARS, USDA, Beltsville, Md. He writes that "the specimen is very interesting, but unfortunately is immature."

George N. Wolcott

Department of Entomology 